\title{
Fifty years after introduction: muskrat Ondatra zibethicus population of Khar-Us Lake, Western Mongolia
}

\author{
Mogoltsog Otgonbaatar, Setev Shar* \& Alexander P. Saveljev
}

\begin{abstract}
The first release of the muskrat (Ondatra zibethicus) in the ecosystem of Khar-Us Lake, Western Mongolia, commenced in 1967. A total of 415 individuals were introduced into this watershed until the early 1980's. Subsequently, the distribution of muskrats has expanded exponentially throughout the wetlands of Khar-Us Lake. For example, they are distributed along the Khovd River, the Khovd River mouth, the Dalai Lake and the islands of the Tsagaan River. These habitats are under threat of degradation due to the activities of both humans and domestic animals. The current population of mature muskrats in the Khar-Us Lake is approximately 80,000 individuals. This increased population has had numerous impacts on these ecosystems, suggesting that some measure of control must be established to ensure the population remains sustainable while the ecosystems remain intact. In situations such as this, where an invasive species is inflicting tangible damage to an ecosystem, sustainable harvesting can be necessary for the purpose of regulating their impact. The sustainable hunting of muskrats for their fur is however beneficial to the development of the local economy which in turn strengthens the management plan for the National Park of "Khar-Us Lake".

How to cite this article: Otgonbaatar M., Shar S., Saveljev A.P. 2018. Fifty years after introduction: muskrat Ondatra zibethicus population of Khar-Us Lake, Western Mongolia // Russian J. Theriol. Vol.17. No.1. P.32-38. doi: 10.15298/rusjtheriol.17.1.03
\end{abstract}

KEY WORDS: muskrat, Khar-Us Lake, population dynamic, ecological impact, behavioral adaptations, management.

Mogoltsog Otgonbaatar [otgonbaatar_2004@yahoo.com], Khovd State University, Khovd, Mongolia; Setev Shar [shar@num.edu.mn], National University of Mongolia, Ulaanbaatar, Mongolia; Alexander P. Saveljev [saveljev.vniioz@mail.ru], Russian Research Institute of Game Management and Fur Farming, Kirov, Russia.

\section{Пятьдесят лет после интродукции: популяция ондатры Ondatra zibethicus озера Хар-Ус, Западная Монголия}

\author{
М. Отгонбаатар, С. Шар, А.П. Савельев
}

\begin{abstract}
РЕЗЮМЕ. Первая транслокация ондатры (Ondatra zibethicus) в экосистему озера Хар-Ус (Западная Монголия) была произведена в 1967 г. До 1980 г. в этот водоем было выпущено 415 особей. Затем постепенно произошло естественное расселение ондатры по водно-болотным угодьям оз. Хар-Ус. В частности, ондатра заселила реку Ховд (Кобдо), озеро Далай и острова на р. Цагаан. Эти биотопы находятся под угрозой деградации вследствие воздействия человека и домашнего скота. Современная численность ондатры на оз. Хар-Ус оценивается в 80000 взрослых особей. Возросшая популяция оказывает разностороннее воздействие на экосистему, что определяет необходимость установления контроля за вселенцами. В ситуации, когда инвазивный вид оказывает ощутимое воздействие на экосистему, необходимо использовать отлов для регуляции численности. Кроме того, промысел ондатры и использование пушнины выгодны для развития местной экономики, а также для разработки менеджмент-планов Национального Парка «Озеро Хар-Ус».
\end{abstract}

КЛЮЧЕВЫЕ СЛОВА: ондатра, озеро Хар-Ус, динамика популяции, экологическое воздействие, поведенческие адаптации, управление.

\section{Introduction}

Muskrats Ondatra zibethicus (Linnaeus, 1766) are widely distributed in North America (Willner et al., 1980; Erb \& Perry, 2003; Cook, 2017) with their native range extending from Canada down to northern Mexi-

\footnotetext{
* Corresponding author
}

co. The species has been successfully introduced to Terra del Fuego in South America (Merino et al., 2009). In Eurasia the muskrat was first introduced between 1905-1906 into the Dobřiš Lake near Prague (Andera \& Gaisler, 2012). The five individuals which were initially released grew rapidly in number and the resultant population spread into many Western European countries. Additional introductions were undertaken in 
Germany in 1914, Finland in 1919 and Poland in 1920 (Lavrov, 1957; Sokolov \& Lavrov, 1993; Skyriene \& Paulauskas, 2012).

Muskrats were introduced into the ecosystems of the Russian Federation for a period of 90 years. Published papers show that records of their translocations since 1928 are incomplete (see Sokolov \& Lavrov, 1993; Chashchukhin, 2007; Bobrov et al., 2008). One primary source (Pavlov et al., 1973) of information is present in the private archive of Dr. Mikhail Pavlov, in an unpublished manuscript of the fifth volume of "Acclimatization ...". With the permission of the Pavlov family, we present in this paper the most complete account of this process which has been offered to date. This archive records muskrat translocations in Russia (and the Soviet Union) from 1928 to the time of "Perestroika" in 1991. In this time 354,086 muskrats were introduced into Russian ecosystems. Within the territory of the former USSR a total 470,467 muskrats were introduced.

Muskrats from the Russia Federation came to Mongolia in or around the 1940's (Dash, 1967; Dash \& Bold, 1968; Pan \& Ye, 1992; Shar et al., 2013; Saveljev et al., 2015). Eregdendagva (1961) noted that since 1946 the species had spread widely in the water courses feeding into the Tsukh (Sukh), Khovd, Gatsaa, Khuder and Uyalga rivers. This information indicated that muskrats came to Mongolia via the Selenge River. Dash (1967) stated that some local herders have been hunting this species since 1942. In Mongolia, the current range of the muskrat is believed to include the Selenga, Orkhon, Khyaran, Khuder, Kharaa, Yeruu, Buir, Onon, Ulz and Duch rivers. This distribution includes the Gun and Gyalaan lakes (Namnandorj, 1964; Dawaa et al., 1977, 1983). A total of 415 individuals were introduced into the Khar-Us Lake, the Chono Kharaikh River, the Dalai Lake, the Bulgan River, the Zeregin Tsagaan Lake in Khovd Province, the Olon Lake in Bulgan Province and the Khar and Shar lakes in Uvs Province between 1967 and 1980 (Dash, 1993). The population around Khar-Us Lake has grown steadily and the species is now common in its surrounding wetlands.

Khar-Us Lake and its surrounding environments were declared as a national park in 1997. This area now covers 850,272 hectares, and includes the Jargalant Khairkhan Mountains (one of the largest ranges of the Mongol Altai Mountains) as well as the largest lakes in the Great Lakes Depression, such as the Khar-Us, Khar and Durgun lakes. The park stretches $115 \mathrm{~km}$ from north to south and $137 \mathrm{~km}$ from west to east. The total length of its border is $509.2 \mathrm{~km}$ (Tserensodnom, 1971). The core distribution of muskrats in the park extends to 321,360 hectares, which includes the Khar-Us, Khar and Durgun lakes, together with their shores and wetlands. These wetlands are registered in the appendix of the Ramsar Convention (1999).

Plants such as rushes (Scirpus hippolitii), reeds (Phragmites australis), sedges (Carex lithophyla) and seaside arrowgrass (Triglochin maritina) are abundant on the bigger islands around Khar-Us Lake. The meadow vegetation with salty soil is dominated by plants such as dryspike sedge (Carex enermis), and rushes (Juncus salsuginosus). The area also has grasses such as bentgrass (Agrostis brini), and meadow-grass (Poa tibetica, $P$. palustris). The soil in the floodplains of the lakes easily becomes salty due to the proximity of the ground water levels to the surface. These areas as a result support sparser vegetation and species with low nutritional demands dominate these habitats.

\section{Material and methods}

This study was undertaken between 2004 and 2014 to determine the distribution, population density, habitat preferences and ecology of muskrats on the natural ecosystem in Khar-Us Lake National Park. Their economic importance was also assessed. Our survey covered 45 study sites on each of the islands of Khar-Us Lake, areas around Khovd River mouth, the Nariin, Baruun and Khovd Rivers, the Nogoon Valley, the Shar lake and in its northern part the Ulaan Tolgoi lake shores, the Shontgor, the inner Khar Tolgoi in Dalai Lake in Durgun sub-province, the lakes in the eastern part of the Mergen Mountains, the Chono Kharaikh River, the Tsakhiurt Valley and the islands of the Tsagaan River. During the course of the study, the locations of 5,609 lodges and burrows were recorded, and related field data were collected. The lodges were counted in the study sites to determine an approximate number and density of individuals based on census approaches developed by Russian experts (Metelskii et al., 1977; Borisov, 1987; Gorshkov et al., 1992). Each of the 45 study sites were $1000 \mathrm{~m}$ long and $50 \mathrm{~m}$ wide. They were chosen randomly within the species core distribution areas on the shorelines and islands of KharUs lake. Figure 1 shows the locations of the study areas and their selected study sites.

In order to describe their habitat conditions adequately additional data on the vegetation structure, the depth of water, the height of shore, the distance from lodge to shore, the velocity of water flow and human or wildlife disturbance was recorded for both muskrat burrows and lodges. The recorded locations of lodges and burrows were entered into a distribution map using ArcGIS 10.3 software, a 1:100000 topographic map and satellite imageries of Khovd Province. Jolly's (1969) method was used to estimate the population density and abundance of muskrats (Krebs, 1999).

\section{Results}

Distribution. The muskrat was introduced into the watershed of Khar-Us Lake 50 years ago. Since introduction it has spread widely through the islands of the Tsagaan River, the Dalai Lake (which is situated to the north of Khar-Us Lake), the islands to the south from Agbash to the small meandering branches of rivers or small ponds around the Khovd River mouth. The musk- 


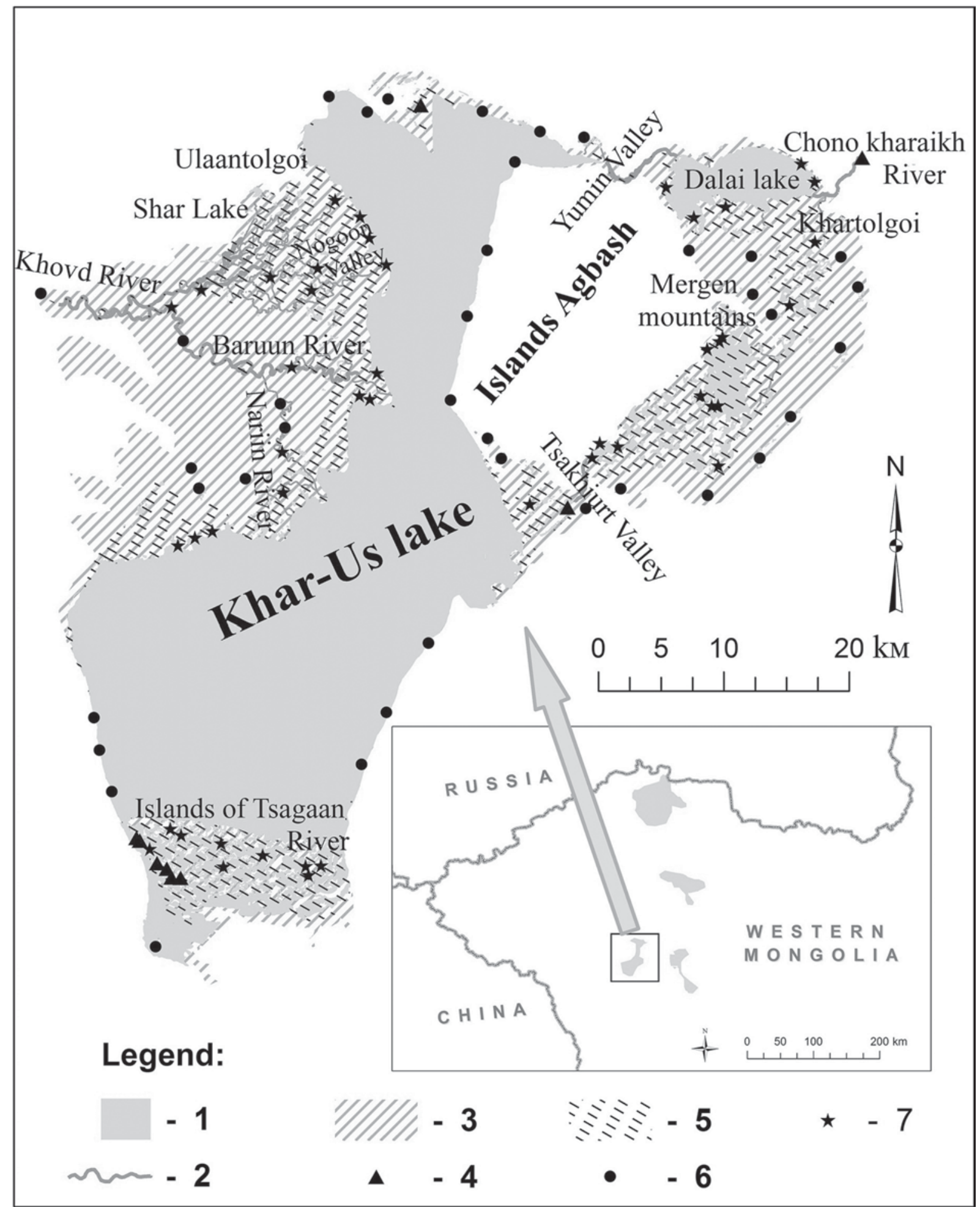

Fig. 1. Distribution of muskrat in Khar-Us Lake. Legend: 1 - lake; 2 - river; 3 - wetlands; 4 - places of introduction; 5 current distribution; 6 - random distribution; 7 - locations of study areas and chosen study sites. 
rat is densely distributed in the northwestern part of Khar-Us lake and in the wetlands with rushes in Khovd River mouth. The density is higher throughout wetlands in northern part of Khar-Us Lake: the shore of Dalai Lake, the Yumin Valley, the Tsakhiurt Valley and the eastern and southern lakes of Agbash Island. The species is also well distributed in the southern part of KharUs Lake and the islands of the Tsagaan River (Fig. 1).

The field study results prove that muskrats are more abundant in these areas due to their preference for habitats such as islands, shores and river mouths with dense vegetation. For example, their distribution of widely overlaps the distribution of the rush (Scirpus hippolitii) due to the importance of this plant in their diet. In addition, the stems, leaves and roots of this species are utilized as the main building materials for their lodges in winter. Dead cane roots play a vital role in providing shelter from the winter cold and for protection from predators. The shelters muskrats hollow out under their dams at the lakeshore create an ideal environment to survive inclement winter conditions.

Population density. The average densities of muskrats along the shore where rushes are abundant in the Khar-Us Lake are illustrated in Figure 2. Annual surveys recorded a decrease in population density between 2004 and 2010 followed by an increase since 2011. The maximum population density was $9.2( \pm 0.4)$ individuals per 1 ha in 2006 and the minimum density was 6.2 $( \pm 0.3)$ individuals per 1 ha in 2010 . The suitable habitats, i.e. those with more rush cover are located in the area around the Khovd River mouth on the northern shore of the Khar-Us lake, the majority of the suitable habitats along the Dalai Lake shore, the bigger lakes and wetlands in the southern and eastern parts of Agbash Island, the island of the Tsagaan River and in the areas along the river shores.

Areas dominated by common reed species and sedges but with low densities or no rush included the lower ends and meanders of the Khovd River, its isolated small lakes and ponds, the Chono Kharaikh River and the Yumin Valley. In these habitats the density of muskrats is relatively low and their populations have fluctuated considerably over time. Figure 2 shows that the highest density was $4.0( \pm 0.6)$ individuals per 1 ha in 2006 with the lowest density being $1.8( \pm 0.5)$ individuals per 1 ha in 2010 in the habitats along the river shore.

Population estimate and resource of muskrat. The introduction of muskrats into the Khar-Us Lake initially aimed to establish a hunting resource. Com-

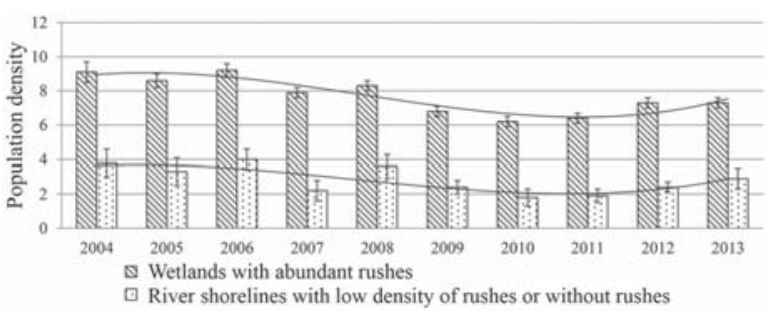

Fig. 2. The population density of muskrats in Khar-Us Lake. mercial hunting started in 1971. In 1972, 3346 pelts were harvested and since then approximately 3.4 to 4.4 thousand pelts have been harvested annually. Dash (1993) estimated that the Great Lake Depressions could sustain 60 to 70 thousand individuals. Since then, no data or estimations of muskrat populations. The status of this population of muskrats is therefore unclear.

In order to identify the home ranges of muskrats we divided the study area into two different groups based on the classification of Dash (1993). The locations of their lodges were also incorporated in this study. The study criteria included: first group - deep lakes with abundant rushes and the second group - rivers and lakes with more sporadic shoreline vegetation. The total of 6,790 ha of aqua- and land areas are attributed to the group of habitats where muskrats build lodges. Our sample capturing system resulted in an average of five individuals per one winter lodge. The population density of muskrats in the wetlands around the Khar-Us Lake was therefore based as an estimate on this figure.

The core area of muskrat distribution covers a total of 6790 ha in area and 1358 linear km along the shorelines including wetlands dominated by rushes and sedges in small lakes, islands, river mouths and tributaries of the Khar-Us Lake. The highest abundance was observed in 2006 with 55307 ( \pm 6262$)$ individuals and the lowest abundance was in 2010 — with $36418( \pm 4858)$ individuals. The population fluctuation of muskrats in Khar-Us Lake in the core distribution area between 2004 to 2013 is illustrated in Figure 3.

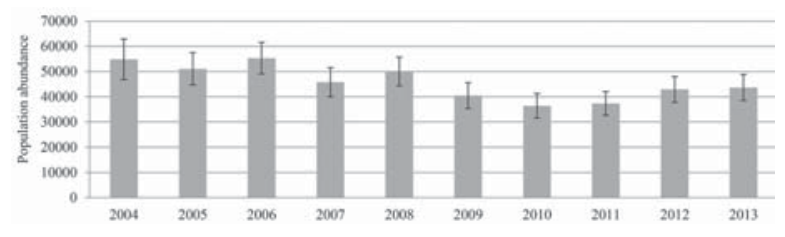

Fig. 3. The population dynamic of muskrats in Khar-Us Lake in the core distribution area for 2004-2013.

Our studies show that the abundance of muskrats is relatively high along the bigger lakeshores with deep water and abundant rushes, but lower along the shores of lakes or rivers with low density of rushes. With regard to the specific status of lodges, $51.2 \%$ of all recorded winter lodges were active, $37.3 \%$ were affected by humans and $11.5 \%$ were affected by wildlife such as wild boar Sus scrofa and red foxes Vulpes vulpes. It is clear that these factors have a significant impact on the dynamics of the muskrat population.

Impacts of muskrat on the ecosystems of KharUs Lake. Muskrats build their lodges on bent rush stems, dead rush roots and on islands. From 50 to $60 \%$ of these structures fall into the water and decay when the ice melts in spring. In addition, $48.8 \%$ of the lodges are destroyed by human or wildlife impacts during the period of ice cover. In some cases, muskrats build their lodges in the shallow water and these freeze to the bottom in the winter. In these locations muskrats dig 
deep channels under the soil to reach the water. There were a number of examples of muskrats spending the winter in the hollow channels they dug under islands without building lodges. With rising water levels, their underground channels and burrows can be sunk, destroyed and abandoned. In such cases the muskrats dig additional channels. During the fluctuating water level, the behavior of muskrats and their home ranges is changing (Otgonbaatar \& Shar, 2009).

On the other hand, the study reveals that as the density of rushes increases the number of muskrat lodges also rises proving that the species has a direct impact this plant. There are many examples of direct muskrat impacts on other aquatic plants in the ecosystem of Khar-Us Lake. Rush (Scirpus hippolitii) is an important species within the plant community of Khar-Us Lake. This plant plays a crucial role in their diet and they have an indirect and direct impacts due to this preferential factor. This relationship between muskrats and rush exploitation is a clear factor in the imbalance of the lake ecosystem.

According to various studies, one adult muskrat consumes between 13 to $37 \%$ of their body mass in vegetation per day. In absolute terms, this can vary from 300g (Stanley, 1928) to $800 \mathrm{~g}$ (Aspisov, 1955). When considering the seasonal dynamics of their forage supply it may be that the annual consumption of a single muskrat could approximate to no less than 100 $\mathrm{kg}$ of raw phytomass. Based on this data, we estimated that the total amount of phytomass consumed by the muskrat population in the ecosystem of Khar-Us Lake is approximately 8000 tons annually. This consumption is mainly based on rush.

Our studies of the "burrow" ecology of muskrats reveal that in the winter months when their trophic relations become tense, that they begin to store vegetation. The most common species stored are reed roots the volume of which can average $2-3 \mathrm{~kg}$.

Where vegetation is scarce muskrats will consume fish and freshwater mussels (Sokolov \& Lavrov, 1993; Shikhova \& Shiryaev, 2017). In rare cases, muskrats will cache fish as a reserve food resource. We also found thirteen Altai osman (Oreoleuciscus potanini) (5-8 cm in body length) in a single winter burrow $90 \mathrm{~cm}$ from the water edge on the Khar-Us Lake. Similar caching behavior has been recorded in other locations. For example, on Sakhalin Island in seven mud houses, food reserves of between 3-5 individuals of "wild" goldfish (Carassius gibelio) were identified. The remains of these fish were identified in the stomach contents of piscivorous muskrats of the Sakhalin (Benkovsky, 1963; cit. in: Sokolov \& Lavrov, 1993, p. 366).

Adaptive behavior of muskrat in conditions of trapping and arid climate. After release into the KharUs Lake ecosystem, the building behavior of the muskrat replicated that in other areas of their Eurasian range. They built two kinds of dwellings - mud houses, or lodges, and burrows. In the late 1980s strong hunting pressure began to impact the muskrat population with the arats (resident hunters) winter hunting techniques resulting in the total destruction of their houses. Our early observations in 1992 and 1993 showed that muskrats when hunted in this way stopped building mud houses and switched to underground burrows. As a result the current population at Khar-Us Lake now lives only in burrows. While this phenomenon could be considered to be an adaptation to human hunting pressure it might also constitute an adaptation to extreme summer temperatures. For example, in Turkmenistan, in the zone of the Karakum Canal muskrats were recorded leaving their houses and moving to open nests and burrows when the temperature daytime reached $+32.3{ }^{\circ} \mathrm{C}$ inside. In their burrow systems the same external temperatures in burrow systems did not exceed $+23.3{ }^{\circ} \mathrm{C}$ with less humidity while in open nests the temperatures remained at around $+20.2{ }^{\circ} \mathrm{C}$ (see Nikitin, 1988). In the winter months these Turkmen muskrats re-occupied their old mud houses. It is obvious that in Mongolian conditions it is impossible during the winter months in some locations to live in houses where intensive human trapping is a factor. In the summer months these structures may become untenable in any case because of high temperatures. As an addition to the forgoing musk rats resting in the summer time in open nests are defenseless against bird of preys, which in the Great Lakes Basin are numerous. These influences on the muskrat population of Khar-Us Lake have resulted in their rapid adoption of an "underground way of life".

The trend of the economic value of the muskrat. The significant changes in the social and economic system in Mongolia in the early 1990s resulted in a high trade value for muskrat pelts. At their peak these were being sold at a price of 10,000 Mongolian tugriks. Almost all were exported to China. The annual game bag of a Mongolian trapper from this region at this time was 50-60 muskrats, from which he earnt half a million tugriks. In the market of Khovd the carcasses of muskrats were sold at a price of 500 tugriks as their meat was considered therapeutic for kidney diseases (see also Saveljev et al., 2014).

Now that their economic importance is less significant improving the managed control of muskrats through targeted hunting for habitat conservation purposes is an urgent challenge in the national park.

\section{Discussion}

Muskrats in some European countries are known to have steadily extended their range at an annual rate of 6 to $8 \mathrm{~km}$ when water depth has positive correlation with the stochastic distribution (Birnbaum, 2013). It is obvious that the population of muskrats which was only initially introduced to Khar-Us Lake has spread widely throughout the other aquatic environments in the national park. While their density varies according to habitat suitability, some studies indicate that it can be up to 15 breeding pairs or 30 individuals per hectare in the most favorable habitat. This compares with over 40 lodges in 3 ha in wetland habitats with rich vegetation 
in southern Michigan and approximately 40 lodges and feeding platforms within 1 ha in swamps in Ontario (Kadlec et al., 2007). Muskrat populations fluctuate seasonally. They attain a maximum in summer and minimum in spring. For example, a minimum of 25 and a maximum of 86 individuals per hectare were registered in suitable habitats in this study. In poorer quality habitats the recorded density was 2 individuals per 1 $\mathrm{km}$ of where water levels often fluctuated (Hatler et al., 2003). In contrast this study provided a population estimate of 9.2 individuals per 1 ha in habitats with rich aquatic vegetation and 1.8 individuals per 1 ha in habitat with a low amount of aquatic plants. The density of introduced muskrats in the Khar-Us lake was therefore relatively low compared with that identified in other areas of the species wider natural or introduced world range.

\section{Conclusions}

We developed the following conclusions based on our study results.

1. The introduced muskrat population in four areas around the Khar-Us Lake including the islands of the Tsagaan River, the Dalai Lake, the Chono Kharaikh River and the Lun Valley is now widely distributed in $\mathrm{reed} /$ rush dominated, wetland habitats.

2. Our study shows that muskrat population in KharUs Lake prefers shores with a vegetative community of $\mathrm{reed} / \mathrm{rush}$ in association with deep water. This favourable habitat creates conditions which maintain a high density, abundance of the species. The principal locations of high population densities are the Khovd River mouth in the northwestern part of Khar-Us lake, along the Dalai Lake shore, in the southern and eastern great lakes, the wetlands of Agbash Island, the islands of the Tsagaan River and in other areas along the river shores. The species density is comparably lower in downstream environments, in the meanders of the Khovd River and in smaller, isolated lakes and ponds. These features therefore restrict the muskrat population density and growth rate.

3. Their process of naturalization to the conditions of the arid climate of the study area coupled with an intensive trapping programme has resulted in the muskrat population developing adaptive changes in their lifestyle.

4. In order to reduce the negative impacts of muskrats in the Khar-Us Lake's ecosystem, the implementation of a sustainable hunting regime based on the monitoring of their population and its distribution would be significant for both conservation and the development of the regional economy.

ACKNOWLEDGMENTS. The authors are grateful to the son of Dr. Mikhail Pavlov, Pavel M. Pavlov (Moscow), for the opportunity to access their family archive containing information about the translocations of muskrats in the Soviet Union and for their permis- sion to use them in this publication. We are also grateful to two anonymous reviewers and personally to Derek J. Gow (Devon, United Kingdom) for improving the earlier version of the article and valuable comments.

\section{References}

Andera M. \& Gaisler J. 2012. [Mammals of the Czech Republic. Description, Distribution, Ecology and Protection]. Prague: Academia. 285 p. [In Czech with English summary]

Aspisov D.I. 1955. [Acclimatization of muskrat in VolgaKama region] // Proceedings of VNIIOZ. Kirov. Vol.14. P.20-53 [in Russian].

Birnbaum C. 2013. Invasive alien species fact sheet - Ondatra zibethicus // Online Database of the North European and Baltic Network on Invasive Alien Species NOBANIS. https://www.nobanis.org/globalassets/ speciesinfo/o/ondatra-zibethicus/ondatra_zibethicus.pdf. Accessed 20 February 2017.

Bobrov V.V., Warshavsky A.A. \& Khlyap L.A. 2008. [Alien Mammals in the Ecosystems of Russia]. Moscow: KMK Scientific Press. 232 p. [In Russian]

Borisov B.P. 1987. [Guidelines for All-Russian Inventory of Muskrat]. Moscow: GlavOkhota. 28 p. [In Russian]

Chashchukhin V.A. 2007. Ondatra: Prichiny i Sledstviya Biologicheskoi Invazii [Muskrat - Reasons and Effects of Introduction]. Moscow: KMK Scientific Press. 133 p. [In Russian]

Cook J.A. 2017. Common muskrat Ondatra zibethicus // Handbook of the Mammals of the World. Vol.7. Rodents II. Barcelona: Lynx Edicions. P.289.

Dash Ya. 1967. [Possibilities and importance of muskrat breeding] // Proceedings of the Institute of Biology MAS, Ulaanbaatar. Vol.2. P.112-127 [in Mongolian].

Dash Ya. \& Bold A. 1968. [Expedition results of muskrat introduction in Khar-Us Lake] // Proceedings of the Institute of Biology MAS, Ulaanbaatar. Vol.3. P.36-47 [in Mongolian].

Dash Ya. 1993. [Muskrat in Great Lakes Depression]. Ulaanbaatar: Institute of Biology MAS. 48 p. [In Mongolian]

Dawaa N., Lchamsuren P. \& Stubbe M. 1983. Stand der Akklimatisation von Ondatra zibethica L., 1766 in der Mongolei // Exploration into the Biological Resources of Mongolia. Vol.3. P.67-69.

Dawaa N., Stubbe M. \& Dorzraa O. 1977. Die Bisamratte Ondatra zibethica (L., 1758) in der Mongolischen Volksrepublik // Beiträge zur Jagd- und Wildforschung. Bd.10. S.342-352.

Erb J. \& Perry H.R., Jr. 2003. Muskrats (Ondatra zibethicus and Neofiber alleni) // Feldhamer G.A., Thompson B.C. \& Chapman J.A. (eds.). Wild Mammals of North America: Ecology, Management, and Conservation. Second edition. Baltimore: John Hopkins University Press. P.311348.

Eregdendagva D. 1961. [Distribution of muskrat in Mongolia]. Scientific report in Proceedings of Mongolian Academy of Science. No.2. P.190-200 [in Mongolian].

Gorshkov Yu.A., Pudovkin A.V. \& Papchenkov V.G. 1992. [Ecology of Muskrats in the River Valleys with adjust- 
able Flows]. Kazan: Kazan Institute of Biology RAS 150 p. [In Russian]

Hatler D.F., Blood D.A. \& Beal A.M.M. 2003. Furbearer management guidelines - Muskrat (Ondatra zibethicus). British Columbia. 6 p. www.env.gov.bc.ca/fw/wildlife/trapping/docs/muskrat.pdf. Accessed 20 February 2017.

Jolly G.M. 1969. Sampling methods for aerial censuses of wildlife populations // East African Agriculture and Forestry Journal. Vol.34. P.46-49.

Kadlec R.H., Pries J. \& Mustard J. 2007. Muskrats (Ondatra zibethicus) in treatment wetlands // Ecological Engineering. Vol.29. No.3. P.143-153.

Krebs C.J. 1999. Ecological Methodology. Second edition. Menlo Park: Addison-Wesley Educational Publishers, Inc. $620 \mathrm{p}$.

Lavrov N.P. 1957. [Acclimatization of Muskrat in USSR]. Moscow: Centrosoyuz. 531 p. [In Russian]

Merino M.L., Carpinetti B.N. \& Abba A.M. 2009. Invasive mammals in the National Parks System of Argentina // Natural Areas Journal. Vol.29. No.1. P.42-49.

Metelskii A.P., Korsakov G.K. \& Plotnikov D.I. 1977. [Guidelines for Inventory of Muskrat]. Moscow: GlavOkhota RSFSR. 32 p. [In Russian]

Namnandorj O. 1964. [Muskrat] // [Strictly Protected Areas and Fauna of People's Republic of Mongolia]. Ulaanbaatar: Academy of Science of People's Republic of Mongolia. P.121-123 [in Mongolian].

Nikitin A.P. 1988. [Adaptive behavior of muskrat in conditions of extreme summer temperatures] // Korytin S.A. (ed.) [Behavior of Hunting Animals]. Kirov: VNIIOZ. P.63-66 [in Russian].

Otgonbaatar M. \& Shar S. 2009. The holes and hat's structure of the muskrat (Ondatra zibethica) in Khar Us Lake // [Environmental Conditions, History and Culture of West Mongolia and Adjacent Regions]. IX International Conference Reports. Khovd, Tomsk. Vol.1. P.18-23.
Pan H. \& Ye R. 1992. [Population of Ondatra zibethica in Xinjiang and utilizing] // Xinjiang Agricultural Sciences. No.3. P.17 [in Chinese].

Pavlov M.P., Korsakova I.B., Timofeev V.V. \& Safonov V.G. 1973. [Acclimatization of Game Mammals and Birds in the USSR]. Vol.1. Kirov: Volgo-Vyatskoe knizhnoe izdatelstvo. 536 p. [In Russian]

Saveljev A.P., Soloviev V.A., Shar S., Otgonbaatar M. \& Scopin A.E. 2014. Contemporary significance of hunting and game animals use in traditional folk medicine in North-West Mongolia and adjacent Tuva // Balkan Journal of Wildlife Management. Vol.1. No.1. P.76-81.

Saveljev A.P., Shar S., Scopin A.E., Otgonbaatar M., Soloviev V.A., Putincev N.I. \& Lhamsuren N. 2015. Introduced semiaquatic mammals in the Uvs Nuur Hollow (current distribution and ecological vectors of the naturalization) // Russian Journal of Biological Invasions. Vol.6. No.1. P.37-50.

Shar S., Samiya R. \& Saveljev A.P. 2013. [Alien mammals of Mongolia] // Dgebuadze Yu.Yu. et al. (eds.). [Invasion of Alien Species in Holarctic]. Yaroslavl: Izdatelstvo Filigran. P.163 [in Russian].

Shikhova T.G. \& Shiryaev V.V. 2017. [Variety of mollusks in the food of the muskrat Ondatra zibethicus] // Proceedings of International Conference "Recent Problems of Nature Use, Game Biology and Fur Farming]. Kirov: VNIIOZ. P.422-427 [in Russian].

Skyriene G. \& Paulauskas A. 2012. Distribution of invasive muskrats (Ondatra zibethicus) and impact on ecosystem // Ekologija (Vilnius). Vol.56. No.3. P.357-367.

Sokolov V.E. \& Lavrov N.P. (eds.). 1993. [Muskrat: Morphology, Systematics, and Ecology]. Moskow: Nauka. 545 p. [In Russian]

Stanley A.C. 1928. The fur animals of Louisiana // Louisiana Department of Conservation Bulletin. Vol.18. P.433.

Tserensodnom J. 1971. [Lakes of Mongolia]. Ulaanbaatar. 19 p. [In Mongolian]

Willner G.R., Feldhamer G.A., Zucker E.E. \& Chapmen J.A. 1980. Ondatra zibethicus - Muskrat // Mammalian Species. No.141. P.1-8. 